\title{
Is vegetation collapse on Borneo already in progress?
}

\author{
Kazimierz Becek ${ }^{1,2}$ (D) Aline B. Horwath ${ }^{3}$
}

Received: 24 November 2015/Accepted: 12 October 2016/Published online: 18 October 2016

(C) The Author(s) 2016. This article is published with open access at Springerlink.com

\begin{abstract}
Vegetation and tropical forests in particular have a central role in mitigating the effects of increasing levels of atmospheric $\mathrm{CO}_{2}$. Photosynthesis is the fundamental process during which $\mathrm{CO}_{2}$ is taken up by plants and fixed into carbohydrates. The effect of temperature on the rate of photosynthesis in different plant species is directly related to degree-days (D-D) as well as the leaf area index (LAI). Throughout the dry season, the reduced net primary productivity is tightly correlated with increasing $\mathrm{D}-\mathrm{D}$, while the reduction in soil moisture leads to progressive canopy thinning, indicated by decreasing LAI. Forest degradation exacerbated by soil erosion and depletion of nutrients in response to high rainfall intensities during the rainy season further disturbs the ecological balance of the entire ecosystem, destabilising it beyond its natural resilience. Given this fact, groundbased evidence and remote sensing-based findings, we propose a climatically induced cascade of events leading to a gradual alteration of the tropical forest ecosystems on Borneo with a diminishing ability to absorb $\mathrm{CO}_{2}$ and release $\mathrm{O}_{2}$. Such a feedback loop, which is primarily triggered by increases in temperature, has potentially dangerous outcome for tropical ecosystems and has already been observed in the north-western state of Brunei Darussalam. The island of Borneo as a whole seems to have reached a level of forest degradation that is beyond a point of no return. In the worst-case scenario, the next niche of stability may be a destruction of tropical forests and the loss of a major proportion of Earth's biodiversity. Our aim is to stimulate further research on such occurrences and inspire the implementation of future preventative measures.
\end{abstract}

Keywords Vegetation collapse $\cdot$ Photosynthesis · LAI · Global warming · Vicious cycle

Kazimierz Becek

kazimierz.becek@pwr.edu.pl

Aline B. Horwath

aline.horwath@gmail.com

1 Wroclaw University of Technology, Na Grobli 15, 50-421 Wrocław, Poland

2 Bülent Ecevit University, Zonguldak, Turkey

3 University of Stirling, Stirling FK9 4LA, UK 


\section{Introduction}

Vegetation could play a significant role in mitigating climate change. However, vegetation itself is affected by the diverse processes associated with climate change such as rising temperatures and altered precipitation patterns, in response to elevated atmospheric $\mathrm{CO}_{2}$ (Adams et al. 2009; Becek and Odihi 2008; Craig et al. 2010; Feeley et al. 2007; van Mantgem et al. 2009; Schlenker and Roberts 2009). Temperature in particular represents the principal control of plant productivity as it drives photosynthesis, evapotranspiration, and ultimately plant growth.

The direct effect of climatic parameters on the photosynthetic primary productivity of trees is reflected in the leaf area index $\left(\mathrm{LAI} ; \mathrm{m}^{2} / \mathrm{m}^{2}\right)$, defined as the total leaf area per unit ground surface area. LAI represents one of the most fundamental measures of many biological and physical processes in the water and carbon cycles. By controlling the interaction between the terrestrial environment and the atmosphere, LAI can be viewed as the major driver of plant productivity as well as biosphere feedbacks on atmospheric energy and water exchanges. The monitoring of the distribution and changes of LAI allows assessing growth and vigour of vegetation. While LAI is known to be influenced by $\mathrm{CO}_{2}$ and other plant resources such as water, nitrogen, and light, the responses of LAI to environmental change are infrequently investigated. However, reduction in LAI has been specifically linked to decrease in soil moisture causing earlier senescence and inevitably leading to forest thinning (Dermody et al. 2007).

Given the significance of the evergreen canopy of tropical forests in protecting soil from erosion, it is important to study the LAI-induced impacts on ecosystems because they may drive a tropical ecosystem into a self-sustaining cycle. Currently, the effects of rising temperatures on tropical forest ecosystems are poorly understood. Therefore, research is needed to elucidate the interconnectedness between temperature, photosynthesis, LAI, soil moisture, and erosion. Herein, we describe a positive-feedback mechanism that links climate and vegetation and that may lead to the collapse of tropical forests. This study broadens the scope of research on the impacts of increased temperatures on tropical forests; such research is currently limited to drought-induced effects. The study shows that under certain conditions, tropical forest ecosystems may be destabilised beyond their natural resilience (Nobre and Borma 2009). A likely outcome of this destabilisation may be that pockets of tropical rainforest and poorly bio-diversified landscape would fallout the scene. We hope that this contribution will stimulate further research on such occurrences and inspire preventative measures in the future.

\section{A vicious cycle}

The various signs that the Earth's climate is in transition include rising air temperatures and changes in precipitation levels as well as the increasing frequency of extreme weather events such as intense and prolonged periods of rain or drought (Christensen et al. 2007; Karl and Knight 1998). Melting ice caps, rises in sea levels, and changes in ecosystems are consequences of these climatic disturbances. Widely accepted climate predictions show that in the coming decades, the average air temperature will increase by approximately $2-4{ }^{\circ} \mathrm{C}$ with respect to long-term historical conditions (Christensen et al. 2007). Setting aside discussions on the causes of climate change (Morgan and McCrystal 2009), we focus in this paper on the impact of global warming on tropical vegetation. Much research has 
previously been done on this topic. The noteworthy effects of climate change include alteration of the composition, spatial distribution, and health of forests throughout the world (Parks and Bernier 2010), increased tree mortality (van Mantgem et al. 2009), reduced crop yields (Schlenker and Roberts 2009), increases in diseases and insect infestations (Netherer and Schopf 2010; Pinkard et al. 2010), wildfires (Liu et al. 2010), and the retreat of coastal forests due to rising sea levels (Doyle et al. 2010). The availability of water, or the lack thereof, for vegetation (Suresh et al. 2010) has been identified as the major factor responsible for deterioration of vegetation. In addition to the central role of soil moisture in controlling ecosystem functioning, the health of vegetation may also be affected by rising temperatures through the temperature-photosynthesis relationship (Botkin 1993; Chambers and Silver 2004). Here, a feedback loop is outlined that involves increases in temperature, and the perpetuating effects on the condition of vegetation and associated natural processes. Given the potentially catastrophic outcomes for tropical ecosystems, this feedback loop is referred to here as the vicious cycle (VC). This $\mathrm{VC}$ seems to be taking place in Brunei, Borneo, where observations of the local forest ecosystem were carried out.

\section{Geography and climate of Brunei Darussalam}

Borneo, the world's third largest island, extends a few hundred kilometres south and north of the Equator in south-east Asia. Borneo is known for its biodiversity, which is among the highest on Earth, and for its tropical forests and deposits of gas and oil. A tiny part of north-western Borneo constitutes Brunei Darussalam. Long-term meteorological observations indicate that for at least the past 40 years, the monthly mean maximum $\left(31.9{ }^{\circ} \mathrm{C}\right)$ and minimum $\left(23.4{ }^{\circ} \mathrm{C}\right)$ temperatures have both been increasing at a rate of 0.23 and $0.33{ }^{\circ} \mathrm{C}$ per decade, respectively. This trend-presented here in terms of degree-days (DD) was estimated by linear regression of the seasonally adjusted monthly mean degreedays - is shown in Fig. 1. It was found that the slope of the regression line is 0.08803 $\mathrm{D}-\mathrm{D} /$ month with the $95 \%$ confidence bounds being 0.08168 and 0.09439 , and $R^{2}=0.668$. The $p$ value of $3.71 \mathrm{e}-90$ indicates that the slope of the seasonally adjusted rainfall trend is

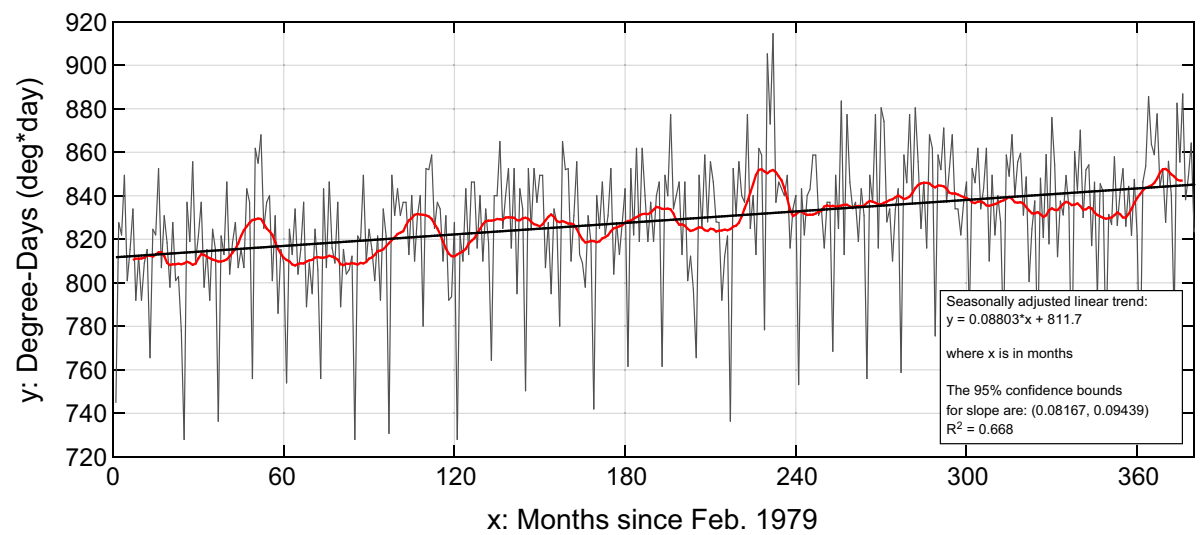

Fig. 1 Monthly mean D-D readings at Brunei International Airport (grey line), seasonally adjusted D-D (red line), and the linear trend fitted to the seasonally adjusted D-D data (black line). Since February 1979, the D-D has increased approximately $3.7 \%$. Source: Brunei Darussalam Meteorological Department 
statistically significant. The temperature has been measured at the Brunei International Airport. The temperature readings at other available meteorological stations in Brunei Darussalam (Brunei Shell, Ministry of Industry and Primary Resources) show similar trends. The rainfall $\left(\sim 3500 \mathrm{~mm}_{\text {year }}{ }^{-1}\right)$ is almost evenly distributed throughout the year. An increase in rainfall of approximately $7 \mathrm{~mm}$ per decade has also been recorded. The trend rate was calculated by the linear regression of seasonally adjusted rainfall data. The $95 \%$ confidence bounds for the slope are 0.409 and $0.988 \mathrm{~mm}_{\text {year }}{ }^{-1}$, with $R^{2}=0.041$. The $p$ value of $2.74 \mathrm{e}-6$ indicates that the slope of the seasonally adjusted rainfall trend is statistically significant. The mean monthly rainfall intensity for the last 40 years is $3.88 \mathrm{~mm} \mathrm{~h}^{-1}$ and exhibits a rising trend. Our tests indicate that the slope of the trend line is statistically significant. The daily rainfall intensity is defined as a ratio of the total rainfall and the time span of the rainfall occurred. The ratio was calculated based on hourly rainfall records, which were subsequently averaged to the monthly mean rainfall intensity. The linear regression was used on the monthly means of the rainfall intensity.

Brunei's surface is composed of soft clay/silt soils. Approximately $75 \%$ of the country's $5765 \mathrm{~km}^{2}$ is covered by rainforest. The topography is flat, with ridges of $\sim 400$ masl found only at the national boundaries. In the eastern Temburong District, the topography is rough, culminating in Mount Pagon (1850 masl). Haze and landslides are common hazards and are always associated with loss of vegetation. Figure 2 shows an example of a severe erosion process caused by high rainfall and the lack of vegetation.

\section{Photosynthesis}

Plant life relies on photosynthesis, which is an extremely complex biochemical process. The foliar parts of the vegetation are essential for the carboxylation reactions catalysed by the enzyme RuBisCo. $\mathrm{CO}_{2}$ fixation during photosynthesis depends on sunlight, water, and atmospheric $\mathrm{CO}_{2}$ and is influenced by temperature. Under optimal conditions absorbed,

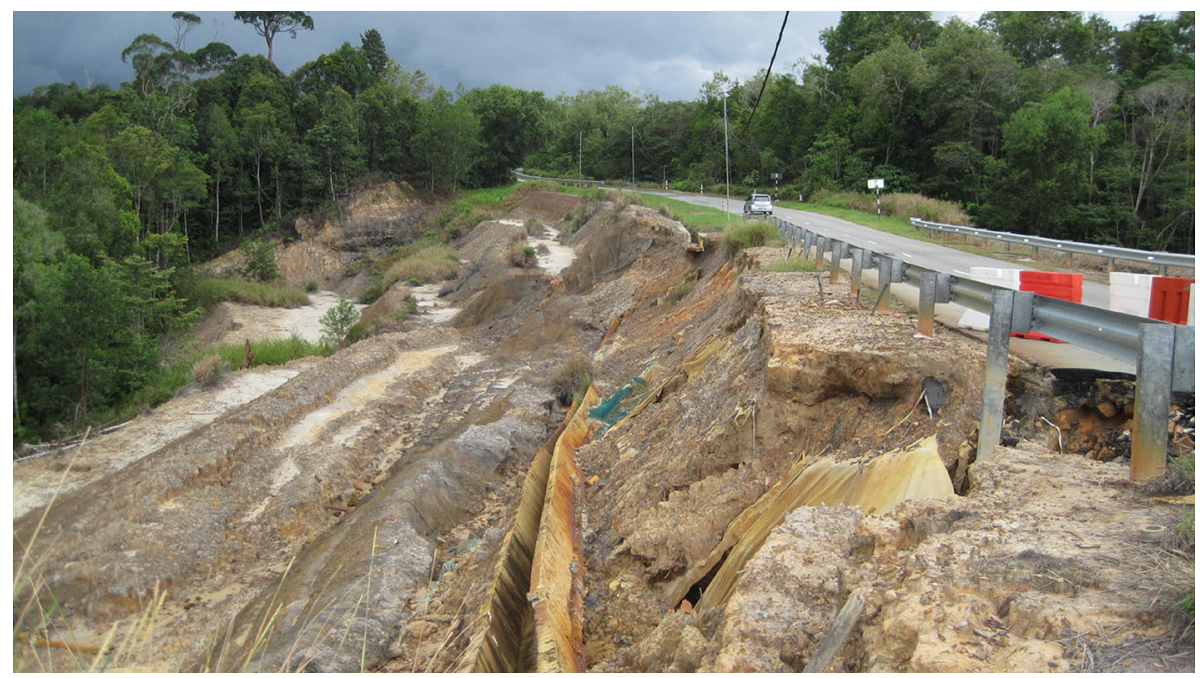

Fig. 2 An illustration of the severity of erosion process, if soil is not protected from rainfall. Labi Road, Brunei Darussalam. Photo: K. Becek 
$\mathrm{CO}_{2}$ is metabolised into carbohydrates, the plants' structural building material, and $\mathrm{O}_{2}$ is released into the atmosphere. A plot of the dependence of photosynthetic rate on temperature (i.e. degree-days, D-D) forms an inverted parabola-like curve (Fig. 3) (Botkin 1993). The highest point represents the maximum rate of photosynthesis and corresponds to the species-specific optimal D-D. Any deviation above or below the optimal D-D produces a reduction in photosynthetic rate. In temperate climates, when the D-D reaches its minimum (e.g. during winter months), photosynthesis ceases. Photosynthesis is also reduced by higher-than-optimal D-D values, which typically occurs during periods of hot weather when the stomata are closed, preventing water loss but also limiting $\mathrm{CO}_{2}$ uptake.

Photosynthetic capacity of different tree species is directly reflected in LAI, which in turn is affected by topography (slope and aspect), elevation above sea level, nutrient availability, soil moisture, air or water pollution, forest fires, and inappropriate forest management.

A lower LAI is associated with reduced rates of $\mathrm{CO}_{2}$ drawdown from the atmosphere, which leads to higher greenhouse gas concentrations in the atmosphere and further temperature increases. An overall reduction in LAI may also contribute to the deceleration of the growth of forests in the tropics (Feeley et al. 2007).

\section{Soil erosion}

The kinetic energy of raindrops and the amount of rainfall are correlated with the degree of soil erosion (Pearce 1976; Ploey et al. 1990). Tree canopies dissipate the erosive power of raindrops. A closed canopy can intercept rainfall and thus decrease the intensity of water falling from forests. This function protects the ecosystem from soil and nutrient erosion, which is extreme for clay- and silt-type soils. Canopies with a higher LAI are able to decelerate falling raindrops and additionally reduce the number (but also size?) of raindrops that could impact the ground with full force. Field experiments have shown that this discharge from forest openings (i.e. areas with no canopy protection) onto ground covered by fallen leaves and other tree parts is $\sim 600 \%$ greater than in areas covered by canopies (Ross and Dykes 1996). Dislocated soil and nutrients may collect in local depressions in

Fig. 3 Intensity of photosynthesis in a plant species versus degree-days (D-D)

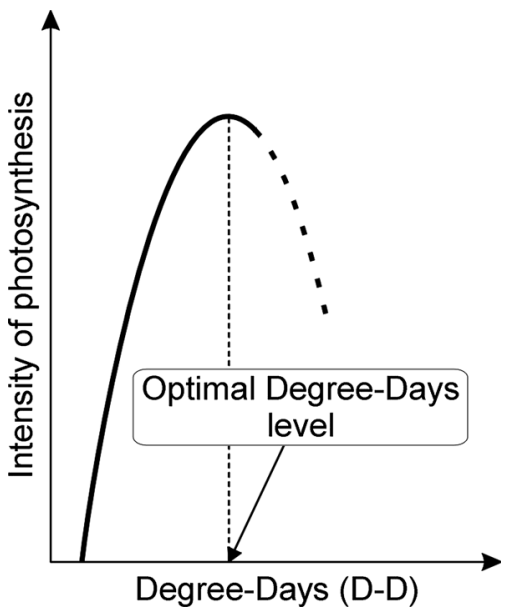


Fig. 4 Trees killed by accumulated water and displaced silt due to erosion. The source of the silt is clearly visible in the upper central part of the photo. This is a site in Berakas along Muara-Tutong Highway, Brunei Darussalam. Photo: K. Becek

which water tends to stagnate. Trees in such ponds are drowned, and thus the canopy protection is lost (Fig. 4).

The nutrients in the ponds are unavailable to the vegetation because they are buried under layers of lifeless silt. Therefore, any decrease in the LAI will cause an increase in soil and nutrient erosion. The effects of soil erosion in the forests may include exposure of tree roots, outbreaks of bark beetles (van Mantgem et al. 2009), damage to the symbiotic and synergic relationships in the tropical environment, and a further decrease in the LAI. An example of how important a tree canopy is in protecting soil from erosion is shown in Fig. 5.

\section{Forest degradation}

A lower LAI allows more sunlight to reach the forest floor, accelerating the drying of soil and facilitating early senescence and further reducing the foliage cover of mature trees. Increased light gaps and a $\mathrm{CO}_{2}$-rich atmosphere could promote the establishment of new trees (Canham 1989). However, these factors may well be counterbalanced by reduced soil moisture, therefore, decreasing rates of photosynthesis and increasing respiration rates due to elevated temperature. Also, more intense competition on the forest floor reduces the availability of nutrients and water and forces trees to maintain canopies with a lower LAI.

A weakened forest may become colonised by exotic species that are resilient to the increasingly harsh conditions. Australian acacia (Acacia auriculiformis and A. pycnantha), introduced to Brunei some 50 years ago, is a good candidate for this role. Acacia phyllodes that accumulate on the ground may fuel wildfires. The burned vegetation makes the ground vulnerable to further erosion and to invasion by other fast growing pioneer species that may contribute to new wildfires and more forest degradation. Figures 6 and 7 show the impact of the exotic species on the tropical rainforest in Brunei.

A decrease in the LAI was detected in Brunei while we were analysing the interaction of the forest canopy with the electromagnetic radiation emitted by synthetic aperture radar (SAR), a satellite remote sensing system (Becek 2011). It has been suggested that, given the absence of obvious forest depleting factors, the lower LAI was a result of increasing temperatures and reduction in soil moisture (Becek and Odihi 2008). Table 1 shows that the areas out of human influences exhibit a lower level of depletion than the remaining forest areas.

Currently, long-term measurements of the integrated solar radiation and temperature in the understory of the tropical forests are being carried out in Brunei with the aim of confirming the trend of decreasing LAI.

\section{Vegetation collapse}

The processes described may work together within a self-sustaining loop, the vegetation collapse loop, hereafter called VC (Fig. 8). The stages of the VC include (a) increasing degree-days, leading to a decrease in the rate of photosynthesis by trees and increase in 


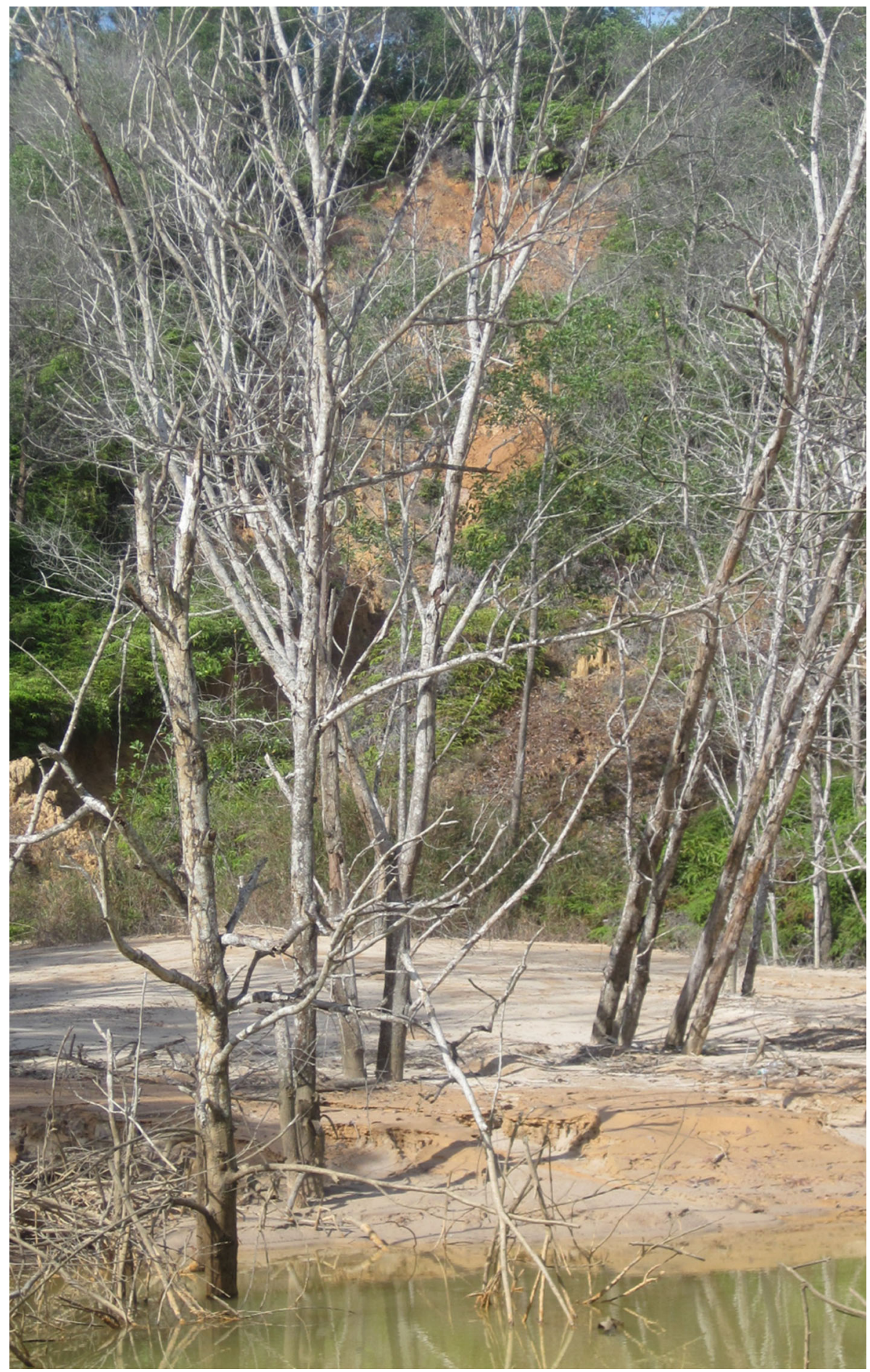


respiratory losses; (b) reduction in leaf cover due to increased senescence in response to decreasing soil moisture; (c) thinning of canopies, allowing more raindrops to pass through the canopy and impact the ground; (d) rainfall producing intense weathering and erosion processes; (e) transport by water of nutrients away from tree roots and the resulting decrease in soil fertility leading to further reduction in LAI; (f) the disruption of the water regime and the nutrient cycle, further exacerbating the thinning of canopies; (g) additional increases in the number and the erosive power of raindrops passing through canopies; (h) stages (c-f) continuing in a sustained loop; (i) increasing diebacks, producing widespread erosion; (j) absorption of smaller amounts of $\mathrm{CO}_{2}$; (k) increasing $\mathrm{CO}_{2}$ levels, causing further D-D and respiration increases; and (l) further canopy thinning as the loop repeats (Fig. 8).

The possible consequences of this VC include a significant loss of vegetation cover, loss of biodiversity, gradual replacement of the native vegetation by opportunistic species, and frequent wildfires. It can be supposed that, under suitable conditions, the first stage of stability for such an evolving tropical ecosystem is complete vegetation collapse. In that case, the climax conditions for the affected ecosystem would result in low vegetation covering moist patches and savannah-type vegetation prevailing over dryer areas.

The VC has the potential to destabilise tropical ecosystems beyond their natural resilience. A destabilised ecosystem tends to follow a sequence of stages (Claussen 1994) rather than exhibiting a single alteration, such as increased tree mortality. A region of stability in the ecosystem may be a catastrophic stage, including the extinction of species and the collapse of tropical forests (Botkin 1993). Such dramatic alterations of tropical ecosystems caused by climate-vegetation feedback have occurred in the past (Charney et al. 1975; Clark 2004; Liu et al. 2006; Zelazowski et al. 2011). Whether this process is already under way in Brunei and other tropical regions remains to be investigated. A few experiments to confirm or otherwise this assertion may be proposed. They include:

- Quantifying forest canopy transparency variations as a function of time and air temperature. This experiment is been currently carried out at a few locations in Brunei forests.

- Observations of the concentration of suspended silt sediments in rivers.

- Observation of impenetrability of forest canopy using remote sensing techniques.

- Measurements of leaves dimensions.

- Estimation of statistics for leaves dropped by trees.

- Increase/decrease in biomass by measurements of the diameter at breast height (DBH).

One of the questions to be asked in regard to the outlined model of transition of tropical forest in Brunei and probably on Borneo and beyond is of the niche of stability which will terminate the VC. In our view, a next region of stability for the ecosystem would be the cessation of one of the major of stressors driving the VC model, i.e. soil erosion. We guess that this will commence when all susceptible to erosion soil layer will be displaced to topographic niches. The process of displacing the soil will also gradually smooth out the topography, i.e. slopes of terrain will become smaller.

This mechanism leads to conclusion that the VC could be able to destabilise the system only there where suitable topographic conditions prevail, that is in a topographic-reach terrain.

We do not believe that VC will develop in a flat areas of forest, e.g. peatland forest which covers some $18 \%$ of the country area. 


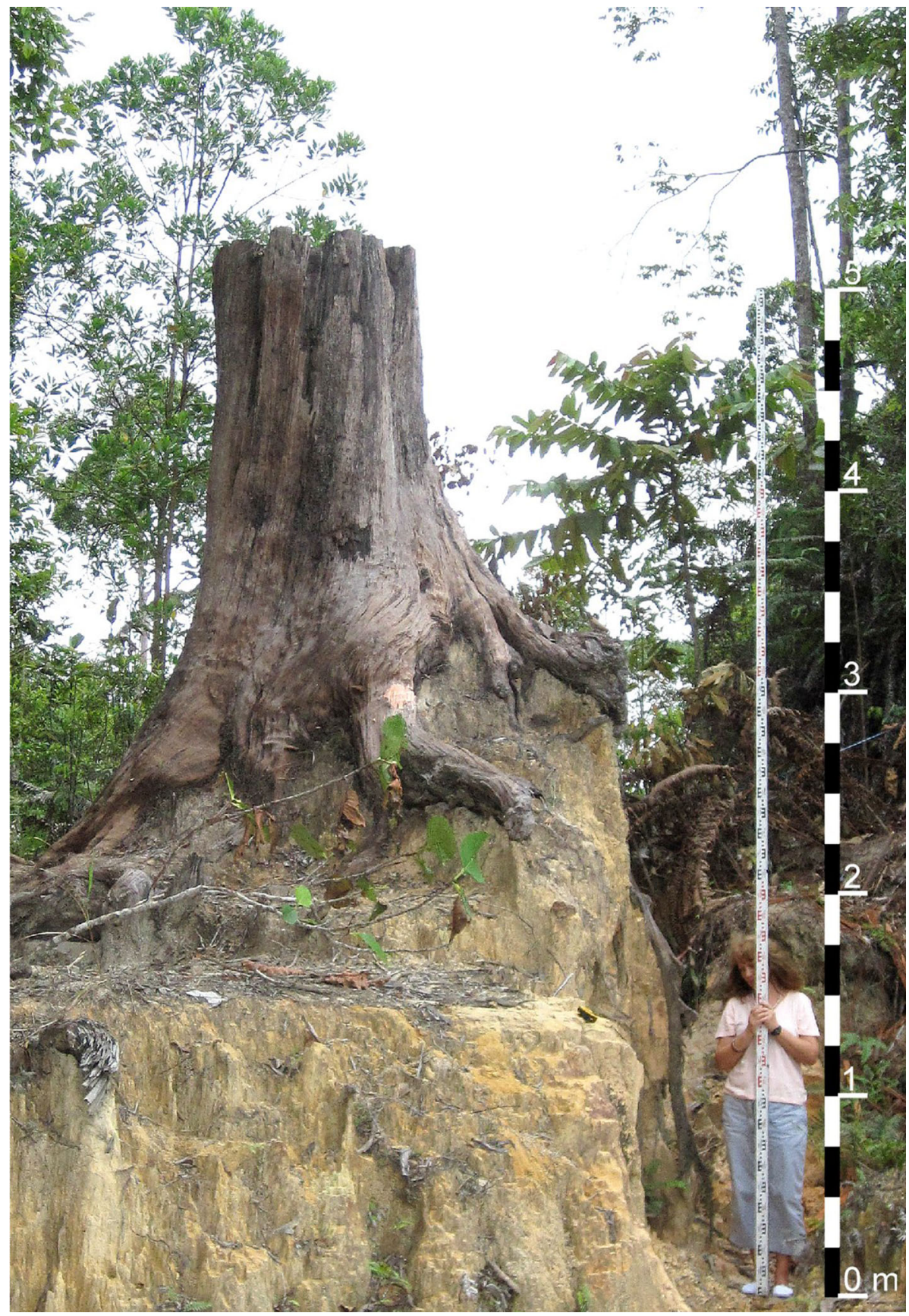

Fig. 5 An example of how important a tree canopy is in protecting soil from erosion. Rainwater caused this deep scar in the ground after the tree canopy was removed. This photo was taken near the Labi Road in Belait District, Brunei Darussalam. Photo: K. Becek 


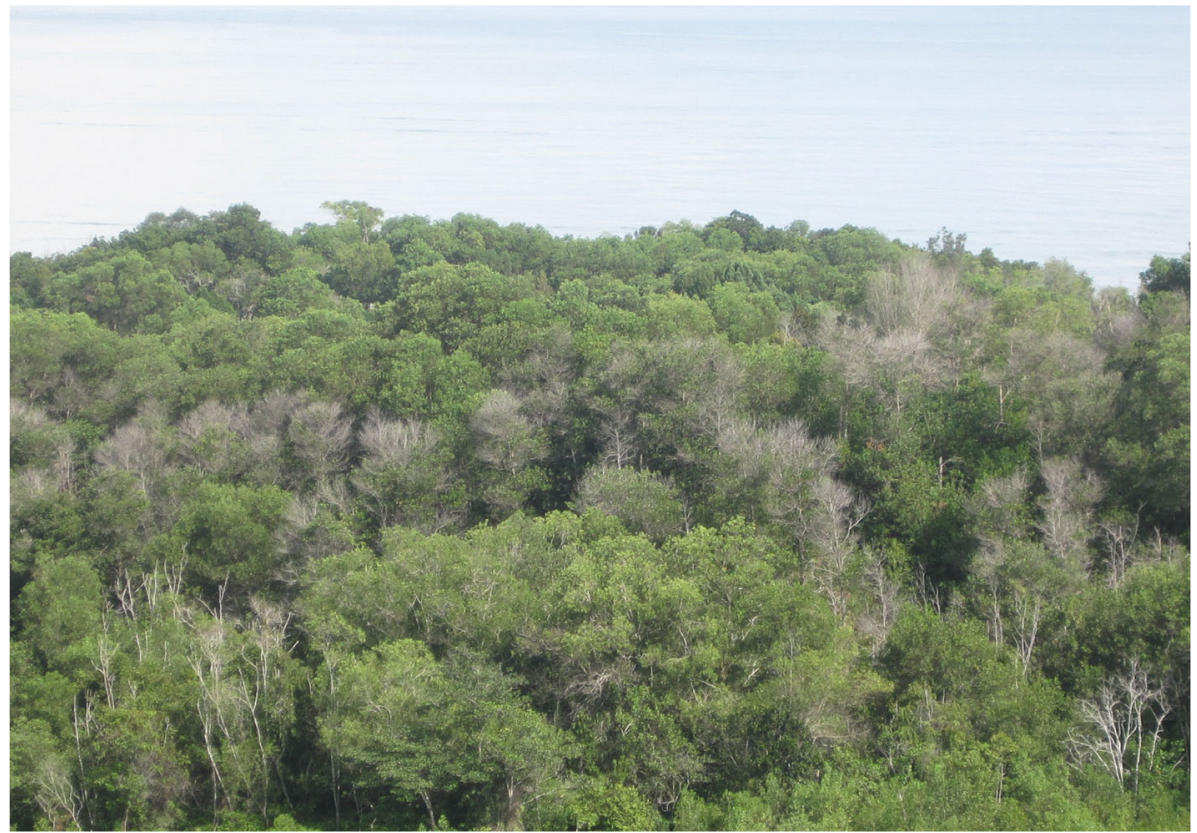

Fig. 6 Berakas forest heavily colonised by Acacia species. A number of fire-damaged trees are easily recognisable. The South China Sea is in the background. Photo: K. Becek

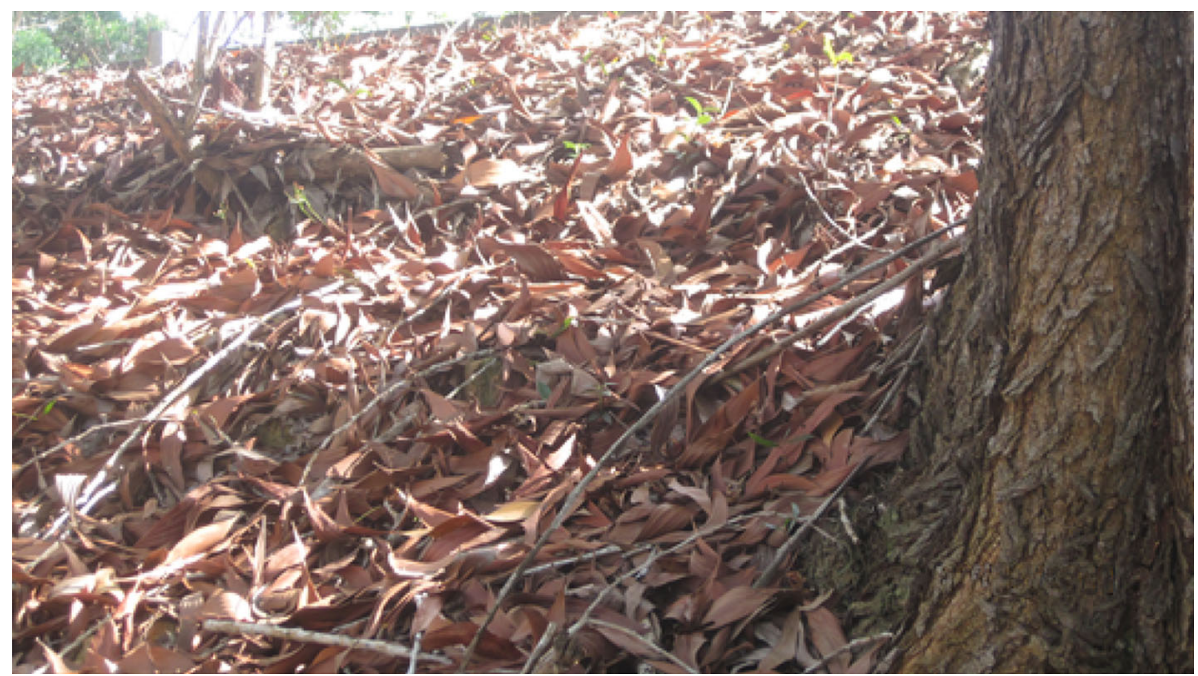

Fig. 7 Invasive Australian Acacia species produce a lot of leaf litter, which tends to accumulate on the forest floor. The decomposition process of this litter is longer than that of the native species, probably due to the absence of suitable micro-organisms. The spread of wildfires can be attributed to the accumulation of such ground litter. Photo: K. Becek 
Table 1 Forest depletion in Brunei (1980-2000) versus forest type and areas under influence of different depleting forces. Source: Table 7 from Becek and Odihi 2008

\begin{tabular}{lll}
\hline Forest type & Depletion $(\%)$ & \\
\cline { 2 - 3 } & Human-active areas & Other areas \\
\hline Mangrove & 25 & 17 \\
Freshwater swamp & 14 & 10 \\
Peat swamp & 17 & 19 \\
Kerangas & 24 & 16 \\
Mixed dipterocarp & 13 & 15.5 \\
Secondary & 26 & 16 \\
\hline
\end{tabular}

The 'human-active' areas refer to forest plots within $2.5-\mathrm{km}$ buffer centred on every village or within $0.5-\mathrm{km}$ buffer from sealed roads. 'Other areas' refer to areas less exposed to human activities

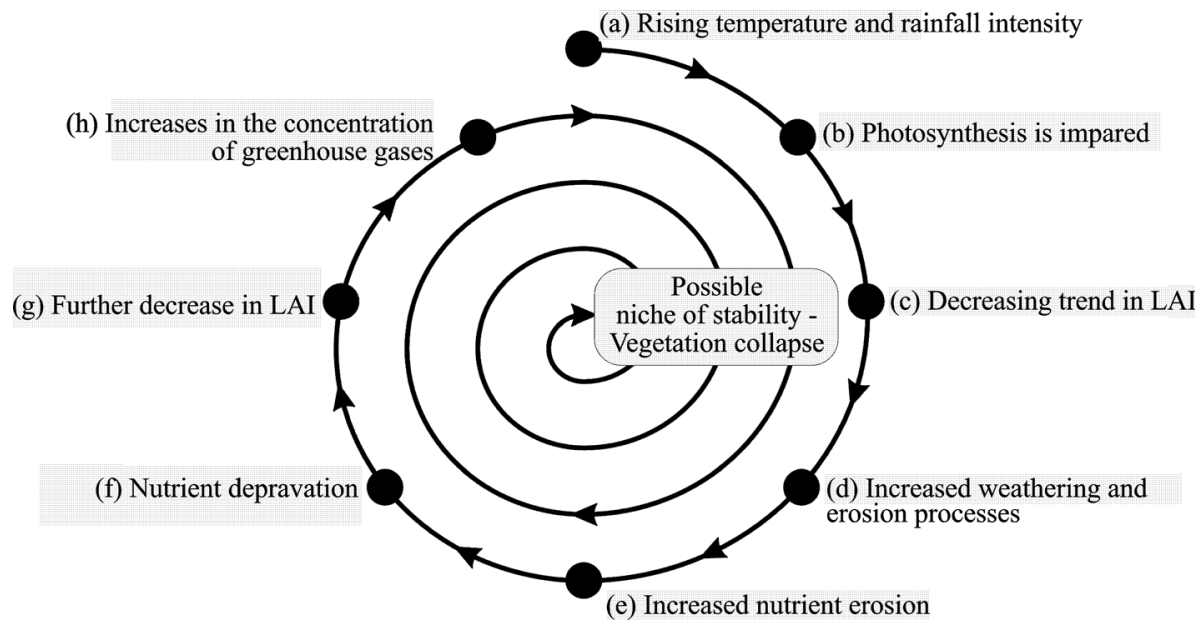

Fig. 8 Simplified temperature-rainfall intensity versus vegetation feedback loop. See the text for more details

Acknowledgments K. Becek gratefully acknowledges financial support provided by the Scientific and Technological Research Council of Turkey while preparing this manuscript. Grant: 2221-(2015/2).

Open Access This article is distributed under the terms of the Creative Commons Attribution 4.0 International License (http://creativecommons.org/licenses/by/4.0/), which permits unrestricted use, distribution, and reproduction in any medium, provided you give appropriate credit to the original author(s) and the source, provide a link to the Creative Commons license, and indicate if changes were made.

\section{References}

Adams HD et al (2009) Temperature sensitivity of drought-induced tree mortality portends increased regional die—off under global—change—type drought. Proc Natl Acad Sci USA 106(17):7063-7066

Becek K (2011) Biomass representation in synthetic aperture radar datasets. LAP, Saarbrücken 
Becek K, Odihi OJ (2008) Identification and assessment of factors affecting forest depletion in Brunei Darussalam. In: Proceeding of the XXI congress of int soc photogram XXXVII (B2-1), pp 209-213

Botkin DB (1993) Forest dynamics: an ecological model. Oxford University Press, Oxford

Canham CD (1989) Different responses to gaps among shade-tolerant tree species. Ecology 70(3):548-550

Chambers JQ, Silver WL (2004) Some aspects of ecophysiological and biogeochemical responses of tropical forests to atmospheric change. Philos Trans R Soc B 359:463-476

Charney JG, Stone PH, Quirk WJ (1975) Drought in the Sahara: a biogeophysical feedback mechanism. Science 187:434-435

Christensen JH et al (2007) Regional climate projections, climate change, 2007: the physical science basis. In: Contribution of working group I to the 4th assessment report of the IPCC. University Press, Cambridge, pp 847-940 (Ch. 11)

Clark DA (2004) Sources or sinks? the responses of tropical forests to current and future climate and atmospheric composition. Philos Trans R Soc B 359:477-491

Claussen M (1994) Coupling global biome models with climate models. Clim Res 4:203-221

Craig D et al (2010) A global overview of drought and heat-induced tree mortality reveals emerging climate change risks for forests. Forest Ecol Manag 259(4):660-684

Dermody O, Weltzin JF, Engel EC, Allen P, Norby RJ (2007) How do elevated $\mathrm{CO}_{2}$, warming, and reduced precipitation interact to affect soil moisture and LAI in an old field ecosystem? Plant Soil 301:255-266

Doyle TW et al (2010) Predicting the retreat and migration of tidal forests along the northern Gulf of Mexico under sea-level rise. Forest Ecol Manag 259(4):770-777

Feeley KJ, Wright SJ, Nur Supardi MN, Kassim AR, Davies SJ (2007) Decelerating growth in tropical forest trees. Ecol Lett 10:461-469

Karl TR, Knight RW (1998) Secular trend of precipitation amount, frequency, and intensity in the United States. Bull Am Meteorol Soc 79:231-242

Liu Z, Wang Y, Gallimore R, Notaro M, Prentice IC (2006) On the cause of abrupt vegetation collapse in North Africa during the Holocene: climate variability vs. vegetation feedback. Geophys Res Lett 33:L22709

Liu Y, Stanturf J, Goodrick S (2010) Trends in global wildfire potential in a changing climate. Forest Ecol Manag 259(4):685-697

Morgan G, McCrystal J (2009) Poles apart: beyond the shouting, who's right about climate change? Random House, New Zealand

Netherer S, Schopf A (2010) Potential effects of climate change on insect herbivores in European forestsgeneral aspects and the pine processionary moth as specific example. Forest Ecol Manag 259(4):831-838

Nobre CA, Borma LDS (2009) 'Tipping points' for the Amazon forest. Curr Opin Environ Sustain 1:28-36

Parks CG, Bernier P (2010) Adaptation of forests and forest management to changing climate with emphasis on forest health: a review of science, policies and practices. Forest Ecol Manag 259(4):657-659

Pearce AJ (1976) Magnitude and frequency of erosion by hortonian overland flow. J Geol 84(1):65-80

Pinkard EA et al (2010) Process-based modelling of the severity and impact of foliar pest attack on eucalypt plantation productivity under current and future climates. Forest Ecol Manag 259(4):839-847

Ploey JD, Kirkby MJ, Ahnert F (1990) Hillslope erosion by rainstorms - a magnitude-frequency analysis. Earth Surf Proc Land 16(5):399-409

Ross SM, Dykes A (1996) Soil conditions, erosion and nutrient loss on steep slopes under mixed dipterocarp forest in Brunei Darussalam. In: Edwards DS, Booth WE, Choy SC (eds) Tropical rainforest research-current issues. Kluwer, Dordrecht

Schlenker W, Roberts M (2009) Nonlinear temperature effects indicate severe damages to U.S. crop yields under climate change. Proc Natl Acad Sci USA 106(37):15594-15598

Suresh HS, Dattaraja HS, Sukumar R (2010) Relationship between annual rainfall and tree mortality in a tropical dry forest: results of a 19 year study at Mudumalai, Southern India. Forest Ecol Manag 259(4):762-769

van Mantgem P et al (2009) Widespread increase of tree mortality rates in the Western United States. Science 323(5913):521-524

Zelazowski P, Malhi Y, Huntingford C, Sitch S, Fisher JB (2011) Changes in the potential distribution of humid tropical forests on a warmer planet. Philos Trans R Soc A 369:137-160 